\title{
Strategi Peningkatan Efektivitas Ruang Terbuka Hijau Di Perumahan Wisma Gunung Anyar Surabaya
}

\author{
Achmad Ridwan Lubis dan Haryo Sulistyarso \\ Perencanaan Wilayah dan Kota, Fakultas Arsitektur, Desain dan Perencanaan \\ Institut Teknologi Sepuluh Nopember (ITS) \\ e-mail:haryo.its@gmail.com
}

\begin{abstract}
Abstrak-Dalam perkembangannya, masyarakat berusaha untuk memaksimalkan ruang untuk kebutuhan dan aktivitas mereka, terutama kebutuhan ruang untuk perumahan sehingga terjadi persaingan penggunaan lahan yang mengakibatkan berkurangnya ruang untuk kebutuhan ruang terbuka publik. Banyak fasilitas dalam ruang terbuka hijau publik tersebut tidak terawat. Hal ini menyebabkan penghuni perumahan tidak dapat memanfaatkan dengan baik ruang terbuka hijau tersebut. Hal inilah yang menjadi dasar bagi penyusun untuk melakukan studi mengenai Strategi Peningkatan Efektivitas Ruang Terbuka Hijau Publik dengan case studi Wisma Gunung Anyar Surabaya. Tujuan dari penleitian ini adalah untuk merumuskan strategi peningkatan efektivitas ruang terbuka hijau publik di Wisma Gunung Anyar Surabaya dengan tiga buah sasaran yaitu mengetahui karakteristik ruang terbuka hijau publik, identifikasi faktor yang mempengaruhi kurang efektif nya ruang terbuka hijau publik, dan merumuskan strategi peningkatan efektivitas ruang terbuka hijau publik. Untuk sasaran mengetahui karakteristik ruang terbuka hijau publik menggunakan alat analisis deskriptif, untuk sasaran identifikasi faktor yang mempengaruhi kurang efektif nya ruang terbuka hijau digunakan analisis Delphi, dan untuk analisis merumuskan strategi peningkatan efektivitas ruang terbuka hijau publik menggunakan analisis Importance Performance Analisis. Dari analisis yang dilakukan, didapatkan hasil sebagai berikut, faktor yang mempengaruhi kurang efektif nya ruang terbuka hijau publik adalah pembiayaan, kurangnya peran serta penghuni, kurangnya kesadaran penghuni akan pentingnya ruang terbuka hijau publik, perilaku pengunjuang, luas laha, fungsi lahan, fasilitas penunjang, radius pelayanan, dan pengendalian dan pengawasan. Dan untuk peningkatan efektivitas strategi yang dirumuskan adalah optimalisasi jadwal pengambilan sampah penghuni, penambahan fasilitas untuk bersosialisasi berupa bangku dan perbaikan fasilitas olah raga, penanaman tanaman pada ruang terbuka hijau publik seluas $\mathbf{7 0 - 8 0 \%}$ dari luas ruang terbuka hijau publik (PERMEN PU No 5 tahun 2008), perawatan terhadap elemen pengisi ruang terbuka hijau (fasilitas olah raga, sosial, dan tanaman).
\end{abstract}

Kata Kunci- RTH Publik, Wisma Gunung Anyar, IPA

\section{PENDAHULUAN}

$\mathrm{K}^{\mathrm{O}}$ OTA Surabaya pada tahun 2016 dihuni sebanyak 2.963.111 jiwa [1]. Pertumbuhan penduduk di kota besar pada umumnya berasal dari peningkatan jumlah penduduk sebelumnya dan pertambahan penduduk dari luar wilayah kota yang melakukan urbanisasi menuju kota tersebut [2].
Pertumbuhan penduduk yang semakin meningkat mengakibatkan kebutuhan sarana dan prasarana perkotaan terutama kebutuhan akan sarana perumahan bagi masyarakat menjadi meningkat. Rumah adalah bangunan yang berfungsi sebagai tempat tinggal atau hunian dan sarana pembinaan keluarga. Rumah berfungsi sebagai tempat tinggal atau hunian yang digunakan untuk berlindung dari gangguan iklim dan makhluk hidup lainnya, rumah merupakan tempat awal pengembangan kehidupan. Selain berfungsi sebagai pelindung terhadap gangguan alam/cuaca dan makhluk lainnya, rumah juga memiliki peran sosial budaya sebagai pusat pendidikan keluarga, persemaian budaya dan nilai kehidupan, penyiapan generasi muda, dan sebagai manifestasi jati diri [3].

Dalam perkembangannya, masyarakat berusaha untuk memaksimalkan ruang untuk kebutuhan dan aktivitas mereka, terutama kebutuhan ruang untuk perumahan sehingga terjadi persaingan penggunaan lahan yang mengakibatkan berkurangnya ruang untuk kebutuhan ruang terbuka publik (RTH-p). Hal ini bisa kita lihat pada beberapa lingkungan perumahan yang ada saat ini, dimana RTH-p berfungsi sebagai tempat berkomunikasi, tempat bermain, tempat istirahat, dan memberikan rasa aman (pedestrian) [4].

Wisma Gunung Anyar yang terletak di Kelurahan Gunung Anyar Tambak ini. Perumukiman ini adalah permukiman yang diresmikan pada tahun 1993 oleh PT Joyo Bekti Indah, permukiman ini memiliki fasilitas yang memadahi, seperti fasiltas peribadatan, fasilitas hiburan, fasilitas perdagangan dan jasa, dan lain-lain. Menurut data dari PT Joyo Bekti Indah, ketersediaan RTH-p sebesar $2.53 \mathrm{Ha}$ atau hanya $8.9 \%$ dari total luas Wisma Gunung Anyar. Untuk persyaratan luas wilayah, ditentukan bahwa RTH-p paling sedikit 10\% (sepuluh persen) dari seluruh luas wilayah kawasan perumahan [5].

Selain dari luas yang masih tergolong kurang, fasilitas pendukung yang dimiliki oleh RTH-p Wisma Gunung Anyar juga tidak dapat digunakan secara maksimal. Banyak fasilitas dalam ruang terbuka hijau publik tersebut tidak terawat seperti tingginya ilalang, rusaknya fasilias pendukung (jogging track yang tertutupi oleh ilalang, rusaknya lapangan basket, lapangan bola, dan lapnagn volly, dan lain-lain). Hal ini menyebabkan penghuni perumahan tidak dapat memanfaatkan dengan baik RTH-p tersebut.

Berdasarkan kondisi tersebut, terlihat bahwa karakteristik penghuni perumahan akan mempengaruhi pemanfaatan 
ketersediaan RTH-p di lingkungan perumahan dalam kaitannnya dengan kebutuhan dan aktivitas rekreasi penghuni. Hal inilah yang menjadi dasar bagi penyusun untuk melakukan studi mengenai Strategi Peningkatan Efektivitas Ruang Terbuka Hijau Publik di Wisma Gunung Anyar Surabaya.

\section{METODE PENELITIAN}

\section{A. Jenis dan Pendekatan Penelitian}

Pendekatan yang digunakan dalam penelitian ini adalah pendekatan rasionalime yang bersumber pada teori dan kebenaran empirik sensual dan empiris etik [4].

Jenis penelitian dalam penelitian ini adalah deskriptif dengan model penelitian memakai studi kasus (case study).

Karakteristik ruang terbuka hijau memiliki dua buah indikator yaitu karakteristik pengunjung dan karakteristik ruang terbuka hijau publik (RTH-p). Variabel yang digunakan untuk indikator karakteristik pengunjung antara lain usia, jenis kelamin, dan lama tinggal [5]. Sedangkan variabel yang digunakan untuk karakteristik RTH-p antara lain adalah fungsi kegiatan [6] dan luas [7].

Variabel penelitian yang digunakan untuk mengetahui faktor-faktor yang mempengaruhi kurang terawatnya RTH-p antara lain pendanaan [8], sumbangan [8], peran serta penghuni, kesadaran penghuni akan pentingnya RTH-p [8], perilaku pengunjung [9], luas lahan [7], fungsi lahan [10], fasilitas penunjang [8], radius pelayanan [11], dan pengendalian dan pengawasan [11].

Variabel yang digunakan untuk merumuskan strategi peningkatan efektivitas RTH-p antara lain pendanaan [8], sumbangan [8], peran serta penghuni, kesadaran penghuni akan pentingnya RTH-p [8], perilaku pengunjung [9], luas lahan [7], fungsi lahan [10], fasilitas penunjang [8], radius pelayanan [11], dan pengendalian dan pengawasan [11].

\section{B. Mengetahui Karakteristik Ruang Terbuka Hijau Publik}

Analisis Deskriptif digunakan untuk mengetahui karakteristik ruang terbuka hijau. Analisis Deskriptif menggunakan bantuan kuisioner dan wawancara.

\section{Faktor-Faktor yang Mempengaruhi Kurang Terawatnya} Ruang Terbuka Hijau Publik

Dalam analisis faktor yang mempengaruhi kurang terawatnya ruang terbuka hijau publik pada penelitian ini menggunakan teknik analisis Delphi dengan tahapan-tahapannya adalah :

1. Menentukan isu permasalahan yang akan dibahas dan dikomentari oleh responden.

2. Menentukan poin-poin yang akan dimasukan ke dalam kuisioner berupa daftar pertanyaan yang berasal dari variabel penelitian yang berpengaruh.

3. Mengumpulkan dan mengidentifikasi hasil pendapat responden.

4. Menginterpretasi kecenderungan pendapat yang dikemukakan oleh responden.

5. Menyusun pertanyaan untuk kuisioner selanjutnya dan mengkomunikasikan hasil wawancara putaran I

Dalam memakai teknik analisis Delphi, dilakukan lebih dari 1 putaran, dilakukan penyusunan pertanyaan dalam kuisioner untuk putaran berikutnya (2,3 dan seterusnya) dengan catatan bahwa hasil putaran sebelumnya dijadikan basis untuk putaran berikutnya. Penggalian pendapat dalam tahap iterasi ini, penilaian setiap responden dihimpun dan dikomunikasikan kembali kepada semua responden sehingga berlangsung proses belajar sosial dan dimungkinkan perubahan penilaian awal. Iterasi berhenti jika sudah terjadi konsensus, namun jika tidak terjadi konsensus maka yang terpenting adalah mengetahui posisi masing-masing responden terhadap permasalahan yang dibahas.

\section{Analisa Strategi Tingkat Efektivitas Ruang Terbuka Hijau Ruang Terbuka Hijau Publik}

Dalam menganalisa tingkat efektivitas ruang terbuka hijau publik di Perumaham Wisma Gunung Anyar, menggunakan alat analisis Importance Performance Analysis (IPA). Analisis IPA menggunakan banruan kuisioner likert dengan 5 skala. Tahapan analisis IPA adalah :

1. Mengetahui nilai tingkat kesesuaian responden.

2. Merumuskan skor rata-rata kinerja dan harapan.

3. Menentukan titik potong pada diagram.

Setelah melakukan tahapan diatas, masing-masing variabel memiliki nilai yang akan dimasukan kedalam diagram kartesius. Dalam diagram kartesius terdapat empat kuadran, variabel yang memasuki kuadran I menunjukan variabel yang memiliki nilai harapan tinggi namun kinerjanya rendah. Kuadran II menunjukan variabel yang memiliki nilai harapan dan kinerja yang tinggi. Kuadran III menunjukan variabel yang memiliki nilai harapan dan kinerja yang rendah. Kuadran IV menunjukan variabel yang memiliki nilai harapan yang rendah namun nilai kinerjanya tinggi.

Dalam merumuskan strategi peningkatan efektivitas, penulis melihat potensi RTH-p, masalah RTH-p, isu strategis, dan kajian pustaka.

\section{HASIL DAN DISKUSI}

\section{A. Mengetahui Karakteristik Ruang Terbuka Hijau Publik}

Berdasarkan hasil tinjauan pustaka didapatkan variabel yang berpengaruh terhadap karakteristik adalah :

a. Karakteristik Pengunjung

Variabel usia, tingkat pendidikan, status pekerjaan, jenis kelamin.

b. Karakteristik Ruang Terbuka Hijau

Variabel fungsi (kegiatan) dan luas lahan.

Berikut adalah hasil analisa karakteristik pengunjung dan karakteristik ruang terbuka hijau :

Tabel 1

Karakteristik Pengunjung

\begin{tabular}{|c|c|l|}
\hline \multicolumn{2}{|c|}{ Karakteristik Pengunjung } \\
\hline No & Variabel & \multicolumn{1}{c|}{ Keterangan } \\
\hline 1 & Umur & $\begin{array}{l}\text { Rata-rata umur pengunjung di Permukiman } \\
\text { Wisma Gunung Anyar berkisar umur 12-60 } \\
\text { tahun, kegiatannya adalah bermain basket, } \\
\text { bersosialisasi, dan menikmati pemandangan. }\end{array}$ \\
\hline
\end{tabular}




\begin{tabular}{|c|l|l|}
\hline 2 & Jenis Kelamin & $\begin{array}{l}\text { Pengunjung didominasi dengan laki-laki pada } \\
\text { hari kerja, dan perempuan pada hari libur }\end{array}$ \\
\hline 3 & Pekerjaan & $\begin{array}{l}\text { Pekerjaan yang dimiliki pengunjung adalah } \\
\text { pelajar/mahasiswa, pegawai negri, dan } \\
\text { wiraswasta }\end{array}$ \\
\hline 4 & Status Pendidikan & $\begin{array}{l}\text { Pengunjung berpendidikan akhir dari siswa } \\
\text { sampai sarjana 1 }\end{array}$ \\
\hline 5 & Lama tinggal & $\begin{array}{l}\text { Rata-rata pengunjung sudah 3-10 tahun } \\
\text { menetap di Perumahan Wisa gunung Anyar }\end{array}$ \\
\hline 6 & $\begin{array}{l}\text { Frekuensi } \\
\text { berkunjung }\end{array}$ & $\begin{array}{l}\text { Penghuni memlikili frekuensi berkunjung 1-3 } \\
\text { kali dalam seminggu }\end{array}$ \\
\hline
\end{tabular}

Wisma Gunung Anyar memiliki tiga buah ruang terbuka hijau publik (RTH-p), yang berlokasikan di Wiguna Selatan, Wiguna Tengah, dan Wiguna Timur. Masing-masing taman memiliki luas yang berbeda, Wiguna Selatan memiliki luas 0,02 Ha, Wiguna Timur memiliki luas $0,28 \mathrm{Ha}$, dan Wiguna Tengah memiiki luas $0,33 \mathrm{Ha}$. Ketiga ruang terbuka hijau publik ini memiliki radius pelayanan yang cukup baik, yaitu kurang dari $1000 \mathrm{~m}$ dari permukiman penghuni sehingga penghuni dapat mengakses ruang terbuka hijau publik tersebut dengan mudah. Fungsi dari taman Wiguna Timur dan Wiguna Tengah adalah olah raga dan sosial, sedangkan taman Wiguna Selatan memiliki fungsi sosial saja. Setiap RTH-p memiliki potensi dan masalahnya masing-masing, berikut adalah tabel potensi dan masalah RTH-p pada lokasi studi :

Tabel 2

Tabel Potensi dan Masalah

\begin{tabular}{|c|c|c|c|}
\hline \multicolumn{4}{|c|}{ 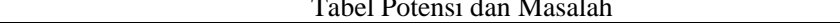 } \\
\hline No & Lokasi & Potensi & Masalah \\
\hline \multirow{3}{*}{1} & \multirow{3}{*}{$\begin{array}{l}\text { Wiguna } \\
\text { Tengah }\end{array}$} & $\begin{array}{l}\text { Luas lahan yang besar } \\
(0.33 \mathrm{Ha})\end{array}$ & $\begin{array}{l}\text { Sering dipakai untuk } \\
\text { lahan parkir dan bakar } \\
\text { sampah }\end{array}$ \\
\hline & & $\begin{array}{l}\text { Tersedianya lapangan } \\
\text { untuk sepak bola dan } \\
\text { volly }\end{array}$ & $\begin{array}{l}\text { Tidak tersedianya } \\
\text { lahan untuk sosialisasi }\end{array}$ \\
\hline & & $\begin{array}{l}\text { Akses dekat dengan } \\
\text { jalan utama }\end{array}$ & $\begin{array}{l}\text { Rusaknya fasilitas } \\
\text { pendukung taman }\end{array}$ \\
\hline \multirow{2}{*}{2} & \multirow{2}{*}{$\begin{array}{l}\text { Wiguna } \\
\text { Timur }\end{array}$} & $\begin{array}{l}\text { Tersedia fasilitas untuk } \\
\text { bermain basket dan } \\
\text { jogging. }\end{array}$ & $\begin{array}{l}\text { Kondisi tanaman dan } \\
\text { pohon yang tidak } \\
\text { terawat }\end{array}$ \\
\hline & & $\begin{array}{l}\text { Tersedia tempat untuk } \\
\text { bersosialisasi }\end{array}$ & $\begin{array}{l}\text { Rusaknya fasilitas } \\
\text { pendukung taman }\end{array}$ \\
\hline \multirow[b]{2}{*}{3} & \multirow{2}{*}{$\begin{array}{l}\text { Wiguna } \\
\text { Selatan }\end{array}$} & $\begin{array}{l}\text { Tersedia tempat untuk } \\
\text { bersosialisasi }\end{array}$ & Luas lahan yang kecil \\
\hline & & $\begin{array}{l}\text { Fasilitas sosial tersedia } \\
\text { dan terawat }\end{array}$ & $\begin{array}{l}\text { Lahan sering } \\
\text { digunakan untuk } \\
\text { menjemur pakaian }\end{array}$ \\
\hline
\end{tabular}

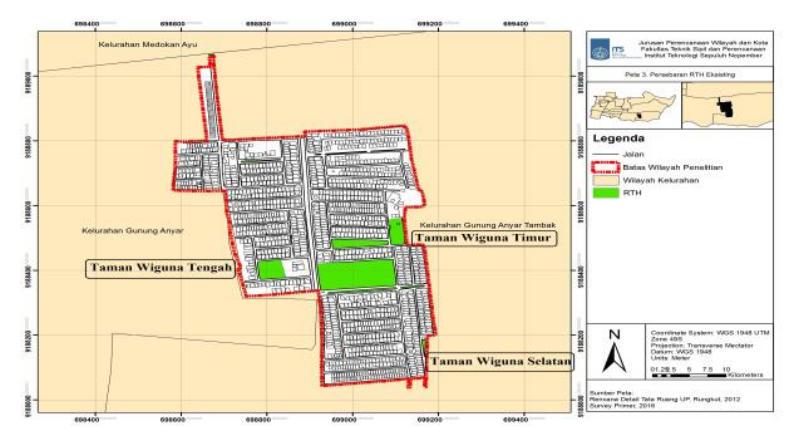

Gambar 1. Peta taman Wiguna Timur dan Wiguna Tengah

\section{B. Faktor-Faktor yang Mempengaruhi Kurang Terawatnya Ruang Terbuka Hijau Publik}

Berikut adalah hasil dari mengidentifikasi faktor yang mempengaruhi kurang terawatnya ruang terbuka hijau publik (RTH-p) :

Tabel 3

Hasil Analisa Delphi

\begin{tabular}{|c|c|c|}
\hline \\
\hline No & Faktor & Hasil Analisa \\
\hline 1 & Pendanaan & $\begin{array}{l}\text { Menurut hasil wawancara yang dilakukan kepada } 25 \\
\text { responden, faktor pendanaan yang bersumber dari } \\
\text { developer merupakan salah satu faktor penyebab } \\
\text { kurang terawatnya RTH-p dikarenakan developer } \\
\text { belom menyerahkan fasilitas umum perumahan } \\
\text { kepada Pemerintah Kota Surabaya. }\end{array}$ \\
\hline 2 & Sumbangan & $\begin{array}{l}\text { Berdasarkan hasil wawancara dengan } 25 \text { responden, } \\
\text { hanya } 19 \text { responden yang menyetujui bahwa sumber } \\
\text { dana dari penghuni juga mempengaruhi kurang } \\
\text { terawatnya ruang terbuka hijau publik di } \\
\text { Permukiman Wisma Gunung Anyar Surabaya. } \\
\text { Belum tercapainya konsesus membuat peneliti harus } \\
\text { melakukan wawancara tahap dua, peneliti } \\
\text { mengganti variabel sumbangan penghuni menjadi } \\
\text { kurangnya pengaruh sumbangan penghuni. Dari } \\
\text { pergantian variabel tersebut } 25 \text { responden } \\
\text { menyetujui, maka telah dicapai konsensus. }\end{array}$ \\
\hline 3 & $\begin{array}{l}\text { Peran serta } \\
\text { masyarakat }\end{array}$ & \multirow{2}{*}{$\begin{array}{l}\text { Program kerja perawatan dan kepedulian berupa } \\
\text { gotong royong sudah dilaksanakan, namun hanya } \\
\text { beberapa orang saja yang mengikuti program kerja } \\
\text { tersebut, sehingga hasil akhir program kerja tersebut } \\
\text { tidak maksimal. }\end{array}$} \\
\hline 4 & $\begin{array}{l}\text { Kesadaran } \\
\text { penghuni akan } \\
\text { pentingnya } \\
\text { RTH Publik }\end{array}$ & \\
\hline 5 & $\begin{array}{l}\text { Perilaku } \\
\text { pengunjung }\end{array}$ & $\begin{array}{l}\text { perilaku pengunjung mencerminkan perilaku yang } \\
\text { justru merusak ruang terbuka hijau publik tersebut. } \\
\text { Berdasarkan keterangan narasumber banyak kaum } \\
\text { muda dan mudi, pengunjung, dan pedagang kaki } \\
\text { lima keliling sering melakukan perusakan seperti } \\
\text { buang sampah sembarangan dan perusakan terhadap } \\
\text { fasilitas ruang terbuka hijau publik. }\end{array}$ \\
\hline 6 & Luas lahan & $\begin{array}{l}\text { Faktor ini dinilai menjadi salah satu faktor penyebab } \\
\text { kurang optimalnya ruang terbuka hijau publik. } \\
\text { Berdasarkan opini narasumber, untuk taman } \\
\text { Wiguna Tengah dan Taman Wiguna Timur memiliki } \\
\text { luas yang terlalu besar sehingga memakan biaya } \\
\text { lebih untuk merawat taman tersebut. }\end{array}$ \\
\hline 7 & $\begin{array}{l}\text { Fungsi } \\
\text { kegiatan lahan }\end{array}$ & $\begin{array}{l}\text { Fungsi kegiatan yang ditunjukan RTH-p pada lokasti } \\
\text { studi tidak menampakan fungsinya dengan jelas } \\
\text { dikarenakan kondidinya yang tidak terawat. }\end{array}$ \\
\hline 8 & $\begin{array}{l}\text { Fasilitas } \\
\text { penunjang }\end{array}$ & $\begin{array}{l}\text { Fasilitas penunjang yang terdapat dalam ruang } \\
\text { RTH-p memiliki kualitas dan kuantitas yang sangat } \\
\text { kurang sehingga tidak bisa di manfaatkan dengan } \\
\text { penghuni. }\end{array}$ \\
\hline 9 & $\begin{array}{l}\text { Radius } \\
\text { pelayanan }\end{array}$ & $\begin{array}{l}\text { Berdasarkan narasumber penelitian radius pelayanan } \\
\text { yang dinilai tidak optimal, karena penghuni lebih } \\
\text { cenderung ke ruang RTH-p diluar permukiman } \\
\text { dikarenakan RTH-p di Permukiman mereka tidak } \\
\text { memiliki fasilitas yang cukup. }\end{array}$ \\
\hline 10 & $\begin{array}{l}\text { Pengendalian } \\
\text { dan } \\
\text { pengawasan }\end{array}$ & $\begin{array}{l}\text { Berdasarkan narasumber pengendalian dan } \\
\text { pengawasan belum bisa dikatakan optimal karena } \\
\text { kurangnya penerangan, tidak ada pagar pembatas, } \\
\text { dan banyak sisi yang tidak dapat terpantau oleh } \\
\text { penghuni dan satuan pengaman permukiman. }\end{array}$ \\
\hline
\end{tabular}




\section{Analisa Strategi Tingkat Efektivitas Ruang Terbuka Hijau Ruang Terbuka Hijau Publik}

Variabel yang memasuki kategori kuadran I adalah pendanaan oleh developer, fasilitas penunjang, dan pengendalian dan pengawasan. variabel yang masuk dalam kategori kuadran II adalah kesadaran penghuni akan pentingnya RTH-p, perilaku pengunjung, luas lahan, dan radius pelayanan. variabel yang masuk dalam kategori kuadran III adalah sumbangan penghuni, peran serta penghuni dalam melestarikan RTH-p, dan fungsi kegiatan lahan.pada kuadran IV tidak ada variabel yang memasuki kuadran ini.

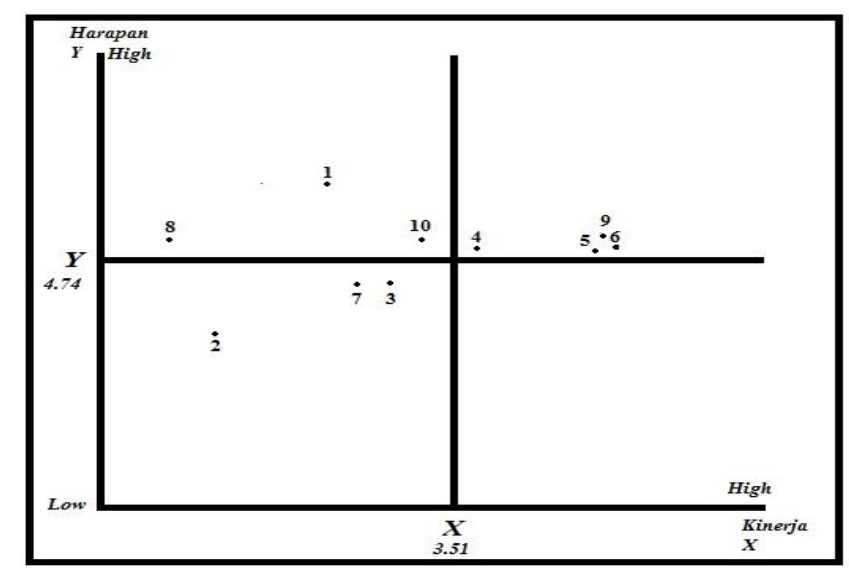

Gambar 2. Diagram Kartesius

Berdasarkan hasil analisa diatas, maka strategi yang dirumuskan adalah :

a. Penambahan fasilitas untuk bersosialisasi berupa bangku dan perbaikan fasilitas olah raga.

b. Penanaman tanaman pada ruang terbuka hijau publik seluas 70-80\% dari luas ruang terbuka hijau publik [11].

c. Perawatan terhadap elemen pengisi ruang terbuka hijau (fasilitas olah raga, sosial, dan tanaman)

\section{KESIMPULAN}

Pada penelitian ini bertujuan untuk merumuskan strategi peningkatan efektivitas ruang terbuka hijau publik di Wisma Gunung Anyar Surabay. Berikut ini merupakan hasil yang diperoleh dari penelitian ini :

1. Karakteristik ruang terbuka hijau publik pada Wisma Gunung Anyar adalah Wima Gunung Anyar memiliki tiga buah ruang terbuka hijau publik, yang berlokasikan di Wiguna Selatan, Wiguna Tengan, dan Wiguna Timur. Dengan luas untuk Wiguna Selatan 0,02 Ha, Wiguna Timur 0,28 Ha, dan Wiguna Tengah 0,33 Ha. Ketiga ruang terbuka hijau publik ini memiliki radius pelayanan yang cukup baik, yaitu kurang dari $1000 \mathrm{~m}$ dari permukiman penghuni Fungsi dari taman Wiguna Timur dan Wiguna Tengah adalah olah raga dan sosial, sedangkan taman Wiguna Selatan memiliki fungsi sosial saja.

2. Berdasarkan hasil analisa diatas, dapat disimpulkan bahwa faktor yang mempengaruhi terhadap kurang terawatnya ruang terbuka hijau publik di Wisma Gunung Anyar Surabaya adalah faktor pendanaan yang bersumber dari developer, faktor pengaruh sumbangan dari penghuni, faktor peran serta penghuni, faktor kesadaran penghuni akan pentingnya ruang terbuka hijau publik, faktor perilaku pengunjung, faktor radius pelayanan, dan faktor pengendalian dan pengawasan terhadap kualitas ruang terbuka hijau.

3. Hasil yang didapatkan dari alat alnalisis Imoprtance-Performance Analisys, pedanaan yang bersumber dari developer, fasilitas penunjang ruang terbuka hijau publik, dan pengendalian dan pengawasan memasuki kuadran I, yaitu faktor yang dianggap penting namum kinerjanya masih kurang. Faktor kesadaran penghuni akan pentingnya ruang terbuka hijau publik, perilaku pengunjung, dan luas lahan memasuki kuadran II yaitu faktor yang dianggap penting dan kinerjanya sudah sesuai. Faktor sumbangan penghuni, peran serta penghuni dalam melestarikan ruang terbuka hijau, fungsi kegiatan, dan radius pelayanan memasuki kuadran III yaitu faktor yang dianggap tidak terlalu penting dan kinerjanya biasa saja. Sedangkan pada kuadran IV tidak ada faktor yang memasuki kuadran ini.Arahan pada tipologi tipe $\mathrm{C}$ diprioritaskan dengan cara peningkatan SDM dengan cara meningkatkan angka partisipasi sekolah sampai tingkat SMP dengan sekolah satu atap, dan peningkatan perekonomian dengan memanfaatkan potensi desa.

\section{DAFTAR PUSTAKA}

[1] "Dinas Kependudukan Dan Catatan Sipil Kota Surabaya Tahun 2016," 2016.

[2] B. Panudju, Pengadaan Perumahan Kota Dengan Peran Serta Masyarakat Berpenghasilan Rendah. Bandung: Alumni, 1999.

[3] S. Yudhosono, Rumah Untuk Seluruh Rakyat. Jakarta: Bharekerta, 1991.

[4] N. Muhadjir, Metodologi Penelitian Kualitatif. Yogyakarta: Rake Sarasin, 1990.

[5] A. M. Yosefa, K. I., \& Navastara, "Karakteristik Pengguna Ruang Terbuka Hijau pada Kawasan Perumahan di Kecamatan Rungkut," $J$. Tek. ITS, vol. 6, no. 2, 2017.

[6] S. . Pramono, "Penataan dan Pemanfaatan Ruang Terbuka (Open Space) Untuk Tempat Berkumpul Informal Di Sepenggal Jalan Slamet Riyadi Surakarta," J. Rural Dev., vol. 1, no. 1, 2010.

[7] R. Indonesia, Peraturan Menteri Negara Perumahan Rakyat Nomor:34/Permen/M/2006 Tentang Pedoman Umum Penyelenggaraan Keterpaduan Prasarana, Sarana, dan Utilitas (PSU) Kawasan Perumahan. Jakarta, 2006.

[8] W. . Widjajanti, "Keberadaan Dan Optimasi Ruang Terbuka Hijau Bagi Kehidupan Kota," Institut Teknologi Adhi Tama Surabaya, 2010.

[9] L. F. Handayani, R., \& Ramadhani, "Perilaku Masyarakat Dalam Penyediaan Ruang Terbuka Hijau Pada Perumahan Di Kelurahan Gunung Sari," J. Perenc. Wil. dan Kota, vol. 5, no. 1, pp. 52-64, 2016.

[10] S. . Kurnia, "Faktor-faktor Yang Mempengaruhi Kurangnya Ketersediaan Ruang Terbuka Hijau (RTH) Publik Di Kota Depok," Univ. Indones., 2013.

[11] P. M. P. Umum, Pedoman Penyediaan Dan Pemanfaatan Ruang Terbuka Hijau Di Kawasan Perkotaan. 2008. 